\title{
REVIEW OF THE BOOK “CULTURAL HYBRIDIZATION IN THE CONTEMPORARY NOVEL" BY DIANA-EUGENIA PANAIT-IONCICĂ
}

Adriana GRIGORESCU ${ }^{1 *}$

Received: February 2021 | Accepted: February 2021 | Published: April 2021

Please cite this paper as: Grigorescu, A. (2021) Review of the book "Cultural hybridization in the contemporary novel" by Diana-Eugenia Panait-Ioncică, Holistica Journal of Business and Public Administration, Vol.12, Iss.1, pp.97-99

\begin{abstract}
The book "Cultural Hybridization in the Contemporary Novel" attempts a bold feat: to present, out of a diversity of works in contemporary English language literature, some books that are truly valuable for the reader. It invites us to ponder on some of the hottest topics the world is currently facing, including the mixture of cultures, migration and its consequences on today's culture and literature, the longing for home and its spiritual meaning.

Keywords: multiculturalism; cultural hybridization; literature in English
\end{abstract}

\section{Introduction}

The book Cultural Hybridization in the Contemporary Novel attempts a bold undertaking: to present, out of a diversity of works in contemporary literature, which were written in the English language, a few of the books that are truly valuable for the reader.

We should highlight the fact that the list of authors which are being commented on in Diana Panait-Ioncică's book is not exclusive. Moreover, she does not rank the authors of the books in any particular order. It is apparent that the writers were selected solely on aesthetic considerations. The choice of writers simply reflects the taste and interests of the author.

It is true that many other writers could have been selected for analysis. Also, there are, perhaps, better books in English literature. The one thing that all the books she has chosen have in common is aesthetic value. This is, we think, the most important criterion for commenting on any book. In current times, dominated by multiculturalism, the aesthetic criterion has been nearly forgotten and replaced with others - such as 'gender' or

\footnotetext{
${ }^{1}$ National University of Political Studies and Public Administration; Associate Member of Academy of Scientist from Romania; Bucharest, Romania, adriana.grigorescu@snspa.ro

* Corresponding author.
} 
'ethnicity'. One will notice, by taking a look at the table of contents, that many of the writers discussed fit the 'multicultural' definition. Some of them are interesting because cultural hybridization is a key feature of their writings. However, cultural hybridization is not the only feature Rushdie, Ishiguro and Ondaatje exhibit; the trait is doubled - or rather, reinforced, by the aesthetic criterion. The mere fact that a writer was born in a foreign country, somewhere in the East, then used the vehicle of the English language for international exposure, is not in any way sufficient to justify his inclusion in a critical study. The reason the above-mentioned writers were chosen was the fact that this biographical accident fortunately contributed to the aesthetic value of their works.

We should note the fact that cultural studies - multiculturalism - promote the idea of multiple cultures. This is an extremely luring concept that adds to the beauty of today's multi-coloured world. When it comes to literary criticism, though, the concept introduces the idea of cultural relativism. As Diana Panait-Ioncică notices, multiculturalism is antiessentialist, in the sense that it excludes criteria of value (aesthetic value) in favour of others, like gender, race, nationality. (Ioncică, 2013) The effect is disconcerting: when it is not the value of the work that counts, but the profile of the author, then literary criticism is in a difficult situation.

The book examines various aspects of cultural hybridization. Although very different in both the relation to the parent-culture and the methods used for constructing the novels, the three writers discussed deal, as Diana loncică notices, with issues related to displacement, migrant identities, homelessness.

One of the main characteristics connecting the three writers is the fact that they share the fundamental experience of migration, of crossing cultural borders - Rushdie was born in Bombay (now Mumbai), India and moved to UK (Cambridge) in 1960; Ishiguro was born in Nagasaki, Japan and emigrated to UK (Guildford) in the same year, and Ondaatje originates from Colombo, Ceylon (now Sri Lanka) and moved to London in 1954, and then settled in Canada in 1962. (Ioncică, 2009) Diana loncică says that the writers discussed in her book also share an "absolute rejection of absolutes", as they cannot choose the simple picture. As she says, in the books' conclusions: "Given the immensely complicated world we live in, rendered even more complex for them by the migrant experience, it would have been nearly impossible to choose to draw a simple picture of the world. Perhaps unfortunately, the times for absolutes has passed, and they only haunt as ghosts (religious fundamentalism, bigotry, fanaticism - and their consequences - terrorism and war) the world we live in." (Ioncică, 2009)

All in all, Cultural Hybridization in the Contemporary Novel makes an interesting read and invites thought on some of the most significant topics our world has to face: the mixture of cultures, the value of home and the aesthetic consequences of migration. ${ }^{2}$

\footnotetext{
${ }^{2}$ We are attaching in the references section, for the benefit of the readers, a list of articles published by the author that could serve as further reading on the topics tackled in the book.
} 


\section{References}

loncică, D. (2006). Through Loss to Revelation - Beautiful Losers and The English Patient. Synergy, volume 2, nr. 1/2006, Bucharest: ASE, ed. Georgeta Ghiga, Tania Măgureanu, 157 pg., pp. 134-143, ISSN 18411-7191, http://www.synergy.ase.ro/issues/2006-vol2-no1/17-throughloss-to-revelation-beautiful-losers-and-the-english-patient.pdf.

Ioncică, D. (2007). The Cost of Free Speech. Synergy, volume 3, no. 1/2007, Bucharest: ASE, ed. Georgeta Ghiga, Roxana Marinescu, pp. 103-113, 147 p., ISSN 1841-7191, http://www.synergy.ase.ro/issues/2007-vol3-no1/14-the-cost-of-free-speech.pdf.

Ioncică, D. (2009). Beyond Postcolonialism. The role of higher education and academic research in the process of development. Creativity and innovation in a culturally diverse, knowledgebased society. New challenges for language teachers, Bucharest, 14-15 May 2009, Bucharest: ASE, coordinator: Georgeta Ghiga, coauthors: Raluca Şerban, Diana Ioncică, Roxana Ciolăneanu, Marina Militaru, Bucharest: ASE, 2009, pp. 104-111, 407 p., ISBN 978606-505- 237-6.

Ioncică, D. (2009). Cultural Hybridization in the Contemporary Novel. Bucharest: Uranus.

Ioncică, D. (2010). Storytelling in 'The Enchantress of Florence'. Languages as a Lifeskill - New Perspectives on LSP Teaching and Learning International Conference, co-organized by The Department of English and German, Bucharest Academy of Economic Studies - QUEST Romania - Grundtvig LLP-Project, Bucharest, Romania, 21-22 May 2010, ISBN 978-606-505363-2, The Proceedings of The Languages as a Lifeskill - New Perspectives on LSP Teaching and Learning International Conference.

Ioncică, D. (2011). Questioning national identities in Kazuo Ishiguro's novels. Youth on the move. Teaching languages for international study and career-building, Bucharest: ASE, 13-14 May 2011, ISSN 2284-6654, ISSN-L 2284-6654, http://limbimoderne.ase.ro/publicatii/youth-onthe-move/pdf/15\%20loncica\%20Diana.pdf.

Ioncică, D. (2013). Highlights of contemporary literature in English. Bucharest: Uranus.

Ioncică, D-E. (2013). Multiculturalism, Multilingualism, Economic Development and Personal Development: An Exploratory Study. International QUEST - ASE - ISQALE Conference 2013 "Improving Standards of Quality in Language Education and Research" within the framework of the Conference series: "Languages for Specific Purposes and Teacher Development" (ISSN 2285 - 1623) Bucharest, 1 - 2 March 2013. 